\title{
Overview of phenotypic plasticity in echinoid larvae, 'Echinopluteus transversus' type vs. typical echinoplutei
}

\author{
Natalie Anne Soars*, Thomas Aelfwyn Arthur Prowse, Maria Byrne \\ Department of Anatomy and Histology and Bosch Institute, F13, University of Sydney, New South Wales 2006, Australia
}

\begin{abstract}
Many sea urchin echinoplutei exhibit phenotypic plasticity, increasing arm length to enhance food capture in nutrient poor conditions. We tested this phenomenon in species with contrasting larval forms reared in similar feeding conditions. Heliocidaris tuberculata has a typical echinopluteus larva with 4 pairs of arms while Centrostephanus rodgersii larvae have only 1 pair of arms ('Echinopluteus transversus' type larva). Larvae were exposed to high, medium and no food treatments. The ratio 'postoral arm length' to 'midline body length' (PO:MBL) was used to document phenotypic plasticity. Fed $H$. tuberculata larvae developed short postoral arms and low PO:MBL, while starved larvae developed long postoral arms and high PO:MBL, indicative of plastic arm growth. In contrast, well fed $C$. rodgersii larvae had the longest arms and high PO:MBL, indicating the absence of plastic arm growth. Taking MBL into account, ANCOVA revealed that differences among treatments were due to PO. The hypothesis that starved C. rodgersii larvae would develop long arms was not supported. Principal component analysis confirmed that larvae in different food treatments had distinct morphologies and that $H$. tuberculata and $C$. rodgersii had opposite growth patterns with respect to food treatment. We suggest that 'Echinopluteus transversus' type larvae are adapted for long distance dispersal, and with only 2 arms for feeding and swimming, there may be an imperative to maintain arm length irrespective of food conditions. Phenotypic plasticity in echinopluteal arm growth is not universal and may be influenced by phylogeny, latitude and the hydromechanics of larval form.
\end{abstract}

KEY WORDS: Phenotypic plasticity $\cdot$ Echinopluteus transversus $\cdot$ Echinometridae $\cdot$ Diadematidae Resale or republication not permitted without written consent of the publisher

\section{INTRODUCTION}

Phenotypic plasticity, the alteration of morphology in response to variations in environmental conditions, is important as it contributes to animal fitness in response to habitat unpredictability (DeWitt et al. 1998, Agrawal 2001, Marchinko 2007). Echinoderms are well known for phenotypic plasticity in both adult and larval life stages (Ebert 1982, 1996, Boidron-Mètairon 1988, Hart \& Scheibling 1988, Strathmann et al. 1992, Fenaux et al. 1994, McShane \& Anderson 1997, George 1999, Podolsky \& McAlister 2005). One of the most familiar examples of phenotypic plasticity is the plastic growth of the arms of the sea urchin echinoplutei in response to different nutritive regimes (Boidron-Mètairon 1988, Strathmann et al. 1992, Fenaux et al. 1994, McAlister 2007, Byrne et al. 2008). Poorly fed larvae increase the length of the postoral arms with respect to body size, thereby increasing the length of their ciliary bands and enhancing food capture (Boidron-Mètairon 1988, Strathmann et al. 1992, Fenaux et al. 1994, Hart \& Strathmann 1994). In contrast, well-fed echinoplutei keep their arms short and allocate resources to early development of the juvenile rudiment, thereby reducing the planktonic larval duration (PLD) (Strathmann et al. 1992). There is a trade-off between investment in larval and postlarval structures with an imperative to enlarge the feeding apparatus when food is scarce or 
allocate to juvenile structures earlier when food is abundant (Strathmann et al. 1992, Hart \& Strathmann 1994). Phenotypic variation in wild caught larvae, i.e. their body profiles, are suggested to be indicative of planktonic conditions in their habitat (BoidronMètairon 1988, Strathmann et al. 1992, Fenaux et al. 1994, Bertram \& Strathmann 1998).

Phenotypic plasticity in larval arm growth has been documented for 21 echinoid species from 10 families (Boidron-Mètairon 1988, Strathmann et al. 1992, Eckert 1995, Bertram \& Strathmann 1998, McEdward \& Herrera 1999, Meidel et al. 1999, Sewell et al. 2004, Miner 2005, Reitzel \& Heyland 2007, Byrne et al. 2008, McAlister 2008) as well as for ophiuroid (Podolsky \& McAlister 2005) and asteroid larvae (George 1999). Recent studies, however, show that some echinoplutei do not exhibit plastic arm growth (Reitzel \& Heyland 2007, McAlister 2008).

Length of the postoral arms when scaled to body size (e.g. midline body length, MBL) is a good indicator of a phenotypic response to food regime (Strathmann et al. 1992, Bertram \& Strathmann, 1998, McEdward \& Herrera 1999). Most authors have studied phenotypic plasticity in typical 8-armed echinoplutei. A recent study indicates that 2-armed diadematid larvae do not not exhibit phenotypic plasticity (McAlister 2008).

The diadematid sea urchin Centrostephenus rodgersii has a 2-armed 'Echinopluteus transversus' type larva. This larval type was named by Mortensen (1921) from specimens found in plankton samples and was only later linked to the Diadematidae (Mortensen, 1937). This unusual pluteus evolved only once in the Echinoidea in the family Diadematidae (Emlet et al. 2002). 'Echinopluteus transversus' larvae develop very long postoral arms while the anterolateral arms remain short. Preoral and posterodorsal arms are vestigial (Mortensen 1921, 1937, Eckert 1998). Here we test the capacity of Centrostephanus rodgersii larvae to alter their body profile with respect to nutritive conditions.

In parallel with our study of Centrostephenus rodgersii, we investigated arm growth of the typical echinopluteus of the sympatric species Heliocidaris tuberculata in differing food regimes. We expected this species to exhibit phenotypic plasticity as reported for the echinometrid Evechinus chloroticus (Sewell et al. 2004).

Heliocidaris tuberculata and Centrostephanus rodgersii inhabit shallow rocky reefs of southeastern Australia (Andrew \& Byrne 2007, Keesing 2007) and have small eggs (ca. 90 and $110 \mu$ m diameters respectively). H. tuberculata larvae have a PLD of 3 to $5 \mathrm{wk}$ (Byrne et al. 2001) while the PLD of C. rodgersii larvae is 3 to 5 mo (Huggett et al. 2005, Andrew \& Byrne 2007). Despite their local abundance and ecological importance (Andrew \& Byrne 2007, Keesing 2007), larval ecology of $H$. tuberculata and $C$. rodgersii is not well studied. In contrast to other diadematids, distribution of Centrostephanus species is not tropical, but temperate, and the capacity of their 'Echinopluteus transversus' larva for phenotypic plasticity is not known. As the postoral arms dominate the larval body of C. rodgersii and grow disproportionately in poorly fed typical echinoplutei, we hypothesised that the larvae of $C$. rodgersii might develop particularly long postoral arms in low food conditions. Alternatively, having only 2 functional arms for feeding and swimming might result in maintenance of long arms irrespective of food conditions. To understand the capacity for phenotypic plasticity in C. rodgersii we reared larvae from 3 independent male-female crosses in differing nutritive regimes and compared them to the typical echinopluteus of $H$. tuberculata. Extending the investigation of phenotypic plasticity and growth dynamics to the larvae of 2 echinoid species from the temperate southern hemisphere with contrasting larval forms addresses the generality of plastic growth in echinoplutei and provides new insights into their growth patterns. We review the distribution of larval phenotypic plasticity in the Echinoidea to assess if different life history characters (e.g. larval type, egg size) or latitudinal distribution provide insights into this phenomenon.

\section{MATERIALS AND METHODS}

Heliocidaris tuberculata (50 to $100 \mathrm{~mm}$ test diameter) and Centrostephanus rodgersii (70 to $100 \mathrm{~mm}$ test diameter) were collected from Little Bay $\left(33^{\circ} 59^{\prime} \mathrm{S}\right.$, $\left.151^{\circ} 15^{\prime} \mathrm{E}\right)$, Sydney, New South Wales. They were induced to spawn by injecting 2 to $3 \mathrm{ml}$ of $0.5 \mathrm{M} \mathrm{KCl}$ into the coelomic cavity. For each experiment 4 to 6 urchins were induced, but only the male and female that produced most gametes were used for crossing. 60 unfertilized eggs per female were photographed (Olympus BX50 light microscope with digital camera) and egg diameters measured using Image J (NIH) software. As larvae in each experiment were full siblings, observed differences between treatments should be due to different feeding regimes and not due to selection for different genotypes (Hart \& Strathmann 1994). The eggs were rinsed in filtered sea water (FSW, $1 \mu \mathrm{m}$ glass filter, Millipore), fertilized with a dilute sperm solution, rinsed again and transferred to $500 \mathrm{ml}$ beakers.

With Centrostephanus rodgersii, 3 independent experiments were performed to document growth of the 2-armed pluteus, each with a separate male-female cross. About $48 \mathrm{~h}$ after fertilisation, before feeding competency, larvae were partitioned at a density of 1 larva $4 \mathrm{ml}^{-1}$ into identical $15 \mathrm{l}$ containers aerated by the same type of plastic air stone and maintained at 17 to $18^{\circ} \mathrm{C}$. Each experiment comprised 9 containers with 3 
allocated to each of 3 food treatments: (1) 12000 algal cells $\mathrm{ml}^{-1}$ (high food, H), (2) 1200 algal cells ml-1 (medium food, M), (3) no food (N). Fed larvae were provided Chaetoceros muelleri, an alga commonly used with echinoplutei (Schiopu \& George 2004, Byrne et al. 2008, Dworjanyn \& Pirozzi 2008) every 2 d. Algae were cultured at $22^{\circ} \mathrm{C}$ in autoclaved, aerated FSW with $1 \mathrm{ml} \mathrm{l}^{-1}$ of $\mathrm{F} / 2$ medium and $1 \mathrm{ml} \mathrm{l}^{-1}$ of silica solution. As the FSW was not sterilised, the treatment may have contained dissolved nutrients and bacteria (Bertram \& Strathmann 1998). $50 \%$ of the water was changed every $4 \mathrm{~d}$ by reverse filtration. In the $C$. rodgersii experiments, 2 had all replicates, i.e. 3 containers per treatment, until Day 12 and 1 until Day 16. Some larvae were reared over $47 \mathrm{~d}$ to document arm growth in advanced stages. For Heliocidaris tuberculata larvae only 1 experiment was conducted as above (3 containers per treatment) with all replicates until Day 12. Some $H$. tuberculata larvae were reared to settlement on Day 47.

For each sampling, 30 larvae from each container were placed in a $1.5 \mathrm{ml}$ tube and preserved by adding 1 drop of $10 \%$ formalin just prior to taking photos (Heliocidaris tuberculata. on Days 1 to 7, 9, 10, 12 and 16; Centrostephanus rodgersii. on Days 1 to 7, 9, 12, and 16). Morphological measurements (Fig. 1) were taken from the photographs using Image J. To facilitate comparison, measurements were taken only from larvae that were in a flat focal plane with arms not tilted. For each container 15 larvae in optimal orientation were photographed, i.e. 45 larvae per treatment. Where necessary, cover slips were used to keep larvae parallel to the focal plane. Larval measurements in-

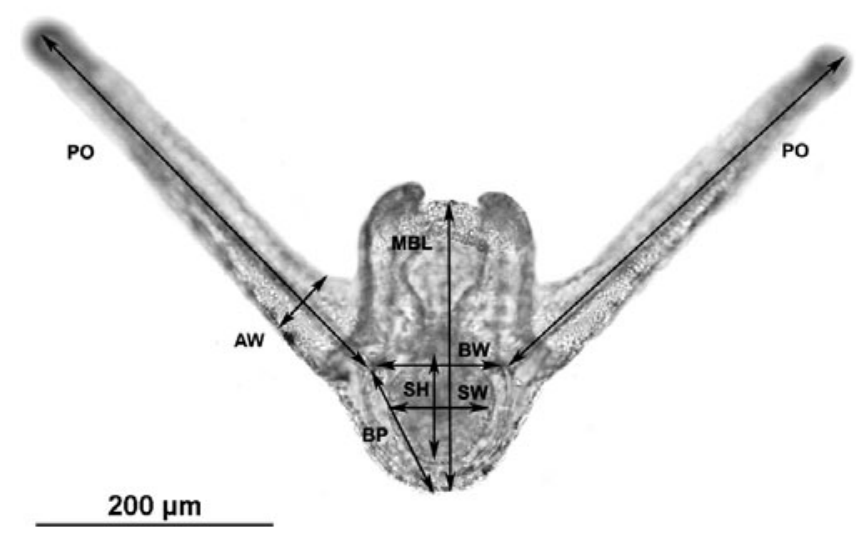

Fig. 1. Centrostephanus rodgersii. Two-armed pluteus (8 d old) showing distances measured for all echinoid larvae in this study. AW: width at the base of the postoral arm, BW: larval body width, BP: length from the anterior end of the body rod to the posterior end of the larva, MBL: midline body length, PO: mean length of both postoral arms, SH: stomach height, SW: stomach width cluded: mean length of both postoral arms (PO), midline body length (MBL), stomach height (SH), stomach width (SW), larval body width (BW), length from the anterior end of the body rod to the posterior end of the larva $(\mathrm{BP})$, larval length $(\mathrm{LL}=\mathrm{PO}+\mathrm{BP})$, and ratio PO:MBL. The width of the postoral arm at its base (AW) was measured on Day 16 in larvae from all treatments ( $n=30$ per treatment). For details see Fig. 1. All values of measurements are mean $\pm \mathrm{SE}$.

These measurements follow those used in other studies (Strathmann et al. 1992, Pedrotti \& Fenaux 1993, Sewell et al. 2004). The PO:MBL ratio was used to document the growth of the postoral arms relative to body size as an indicator of phenotypic response to different food treatments (Strathmann et al. 1992, Bertram \& Strathmann 1998, McEdward \& Herrera 1999). Larval growth was plotted over time. Until Day 6 there was little difference between treatments and full replication for all experiments ended on Day 12. For these reasons data from Day 6 and 12 were used for analysis of variance (ANOVA). Statistics were performed using Systat 11 software. Prior to analysis, homogeneity of variances were checked by plotting residuals against predicted values. Day 12 data for Centrostephanus rodgersii were log transformed to account for unequal variances between treatments. For both sea urchin species, the nested ANOVA included 'Food treatment' as a fixed and 'Container' as a nested factor. As 3 separate experiments were conducted for C. rodgersii a further random factor 'Experiment' was included in the ANOVA model. AW values were also analysed by ANOVA.

To examine plastic growth of the postoral arm, nested analysis of covariance (ANCOVA) was performed on log transformed PO data with MBL as a covariate, using the same structure and days as in the ANOVA model. Slope assumptions were initially tested by fitting the full ANCOVA including all interactions as recommended by Quinn \& Keough (2002). Centrostephanus rodgersii larvae on Day 6 showed a significant 'Experiment $\times$ MBL' interaction which precluded further analysis, but in the remaining instances we fitted a reduced model that excluded interactions that involved the covariate.

When a significant effect of food treatment was detected, Tukey's HSD was used to separate treatment means. To determine morphological distinction of larvae from each treatment and to compare with previous studies (e.g. Hart \& Scheibling 1988, Meidel et al. 1999, Sewell et al. 2004, Byrne et al. 2008), principal component analysis (PCA) was performed using the means for each container on Day 12 for both species (Heliocidaris tuberculata: $\mathrm{n}=9$; Centrostephanus rodgersii: $\mathrm{n}=27$ ). For $\mathrm{PCA}$, we used the parameters $\mathrm{PO}, \mathrm{SH}, \mathrm{SW}, \mathrm{MBL}, \mathrm{BW}$ and BP (see above and Fig. 1). 


\section{RESULTS}

\section{Heliocidaris tuberculata}

Heliocidaris tuberculata eggs $(n=60)$ had a mean diameter of $96 \pm 0.63 \mu \mathrm{m}$ and developed through a typical 8-armed echinopluteus (Fig. 2). The larvae reached the prism stage after $45 \mathrm{~h}$. By Day 2, anterolateral and postoral arm pairs were prominent and by Day 3 the gut was differentiated. Larvae from the 3 treatments on Days 6,12 and 16 are shown in Fig. 2. Stomachs of fed larvae contained algal cells and had pigmented walls (Fig. 2). Unfed larvae had empty stomachs with pale walls. By Day 6 larvae developed posterodorsal arms in all treatments (Fig. 2).
Morphometry of larval growth

There was little or no difference between treatments in any of the larval body parameters up to Day 5 (Fig. 3). On Day 6, PO and LL of fed larvae were similar, while unfed larvae had significantly longer PO and LL than fed ones (ANOVA, Table 1; Fig. 3a). On Day 12 unfed larvae had significantly longer PO and LL than those in the $\mathrm{H}$ treatment (ANOVA, Table 1, Fig. 3a). Neither SW nor MBL was significantly affected by treatment at any stage of the experiment (ANOVA, Table 1; Fig. 3b,c) and SW was particularly variable (Fig. 3b).

From Day 6 the PO:MBL ratios of unfed larvae became significantly greater than in fed larvae (ANOVA, Table 1 ; Fig. 3d). Similarily, unfed larvae had significantly greater

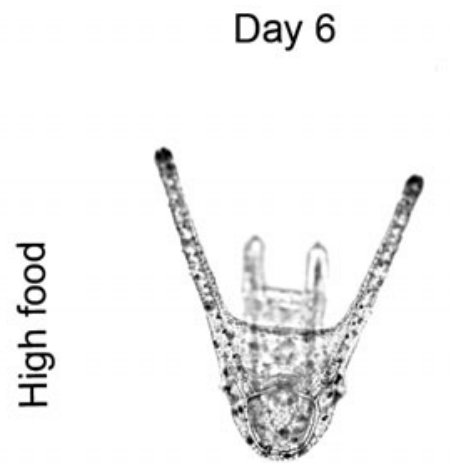

Day 12
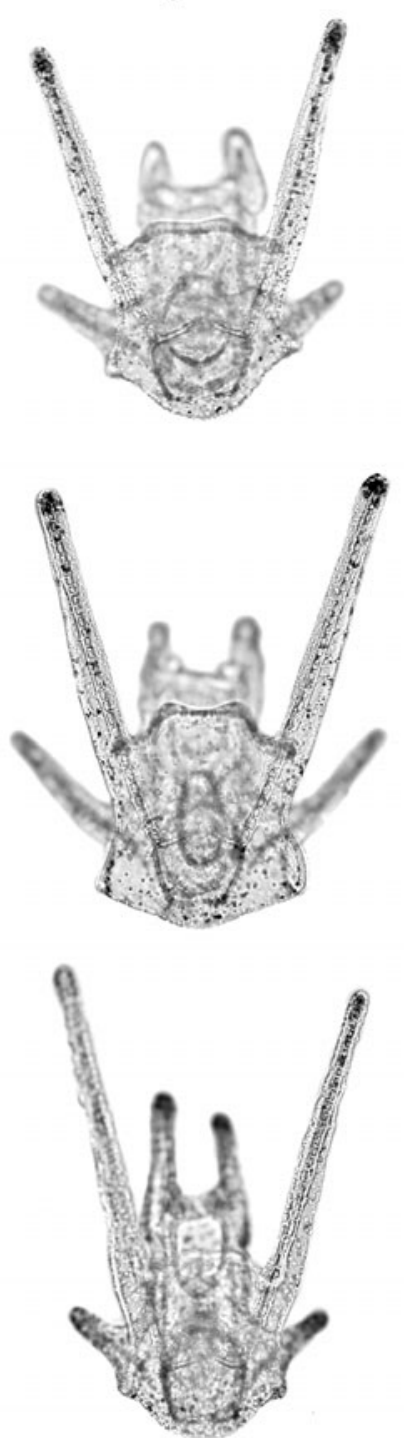

Day 16
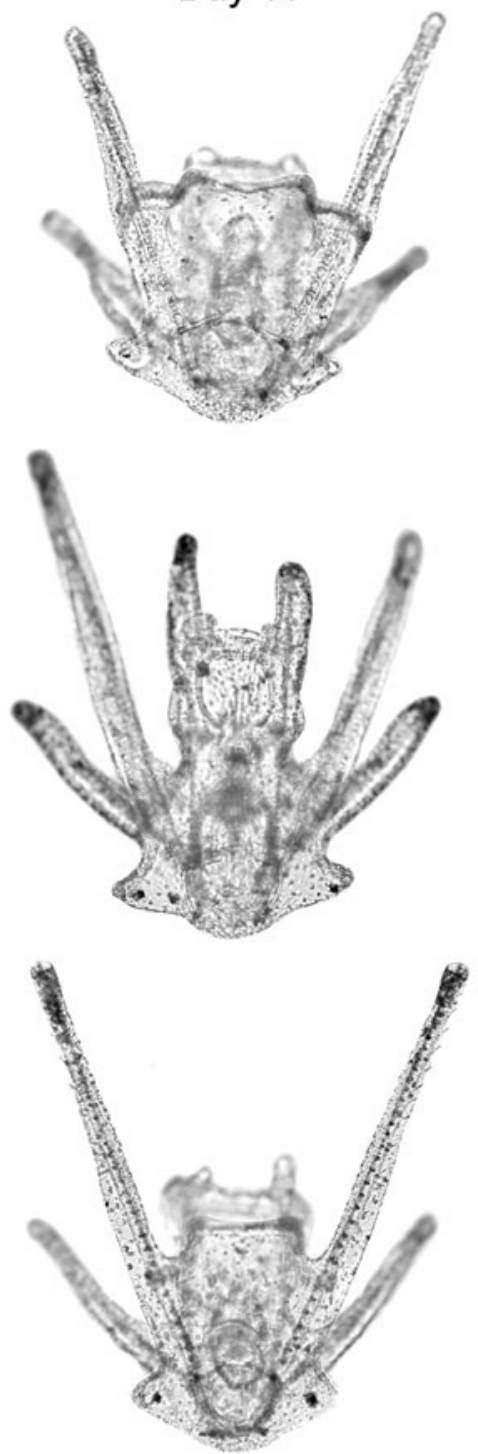

Fig. 2. Heliocidaris tuberculata. Larvae on Days 6, 12 and 16 (columns) from the 3 food treatments (rows) 

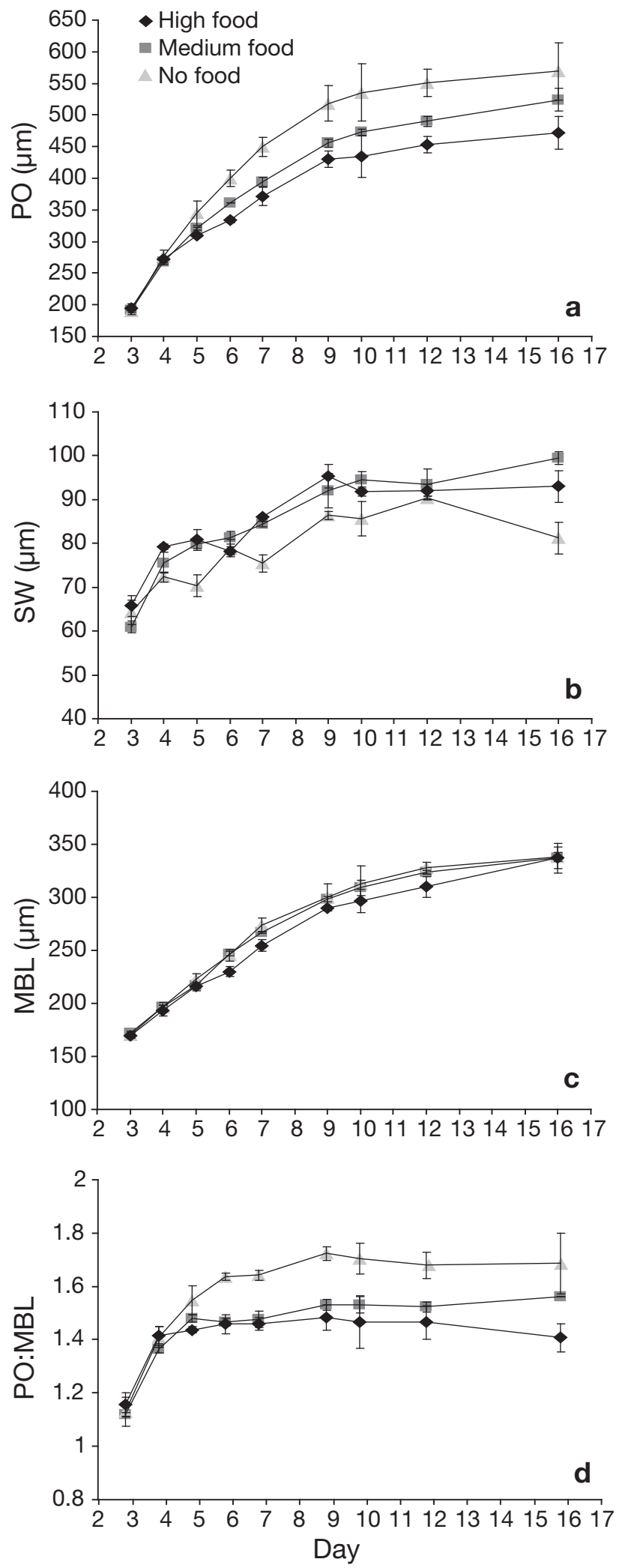

Fig. 3. Heliocidaris tuberculata. Measurements of larvae over time: (a) mean length of both postoral arms (PO), (b) stomach width (SW), (c) midline body length (MBL), (d) PO:MBL ratio. Mean values $\pm \mathrm{SE}$ ratios than high fed larvae on Day 12 (ANOVA, Table 1; Fig. 3d). After adjusting for the covariate MBL, PO differed significantly between food treatments on Day 6 and was greater in unfed than fed larvae (ANCOVA, Table 1). Least squares means for $\mathrm{PO}$ in $\mathrm{H}, \mathrm{M}$ and $\mathrm{N}$ treatments were 340, 357 and 395 respectively, while the covariate MBL was 240. Similarly, after adjusting for MBL, the PO of larvae from the unfed treatment exceeded that of high fed larvae after $12 \mathrm{~d}$ (Table 1). Least squares means for PO in the H, M and N treatments were 464, 485 and 537 respectively while the covariate MBL was 319.

Thus ANOVA of the PO:MBL data and ANCOVA of the PO and MBL data show that PO is longest in unfed larvae. For ANOVA there was a container effect on Day 12 and for ANCOVA there was a container effect on both days. Despite this apparent variation among identical containers, the overall result of long postoral arms in unfed larvae is supported (Table 1).

Fig. 2 illustrates the obvious increase in $\mathrm{PO}$ relative to body size over time. The significantly longer PO in relation to MBL of unfed Heliocidaris tuberculata larvae show phenotypic plasticity with respect to arm growth and food concentration. On Day 12, the mean PO in $\mathrm{H}$, $\mathrm{M}$ and $\mathrm{N}$ treatments was $453 \pm 8 \mu \mathrm{m}, 490 \pm 8 \mu \mathrm{m}$ and $550 \pm 21 \mu \mathrm{m}$, and the PO:MBL ratio $1.47 \pm 0.06,1.52 \pm$ 0.02 and $1.68 \pm 0.05$ respectively ( $\mathrm{n}=45$ with each).

Unfed larvae $(\mathrm{n}=30)$ on Day 16 had mean values for $\mathrm{LL}=670 \pm 41 \mu \mathrm{m}, \mathrm{PO}=569 \pm 44 \mu \mathrm{m}$ and $\mathrm{MBL}=338 \pm$ $4 \mu \mathrm{m}$. The PO:MBL ratios of $16 \mathrm{~d}$ old larvae in $\mathrm{H}, \mathrm{M}$ and $\mathrm{N}$ were $1.41 \pm 0.05(\mathrm{n}=45), 1.45 \pm 0.12(\mathrm{n}=45)$ and $1.69 \pm 0.11(\mathrm{n}=30)$ respectively. There was no difference in AW from the different treatments on Day 16 (ANOVA, $F_{2,6}=3.72, \mathrm{p}>0.05$ ).

\section{Principal component analysis}

PCA of data means for 6 body parameters from all treatments of Heliocidaris tuberculata on Day 12 is shown in Fig. 4 and Table 2. The first principal component represented $68 \%$ of the variation. Coefficients for the first Eigenvector ranged from -0.35 to -0.47 (Table 2) except for PO which was positive (0.36). Thus the first principal component can be interpreted as being representative of the phenotypic plasticity response. The second principal component accounted for $20 \%$ of the variation. Coefficients were both positive and negative with varying absolute value contrasting MBL with PO and stomach size (SW and SH) (Table 2).

The plot of the first principal component against the second one (Fig. 4) represents $88 \%$ of the variation. Data from $\mathrm{H}$ and $\mathrm{M}$ treatments cluster on the left and $\mathrm{N}$ on the right. Thus, larvae from the fed and unfed treatments were morphologically distinct, mainly due to the long PO of unfed larvae. 
Table 1. Heliocidaris tuberculata. ANOVA F-ratios, ANCOVA F-ratios and Tukey's HSD multiple-comparison tests on data for larval measurements taken on Days 6 and 12. H, M and N: high, medium and no food. Significance: ${ }^{*} p<0.05$. Underlined letters: treatments did not differ significantly. np: Tukey's HSD not performed. See Fig. 1 for all other abbreviations

\begin{tabular}{|c|c|c|c|c|}
\hline ANOVA & $\begin{array}{l}\text { Food treatment } \\
\quad(\mathrm{df}=2,6)\end{array}$ & \multicolumn{2}{|c|}{$\begin{array}{c}\text { Container } \\
\text { (Food treatment) } \\
(\mathrm{df}=6,126)\end{array}$} & $\begin{array}{l}\text { Tukey's HSD } \\
\text { groupings for } \\
\text { Food treatment }\end{array}$ \\
\hline \multicolumn{5}{|l|}{ Day 6} \\
\hline $\mathrm{PO}$ & $18.6^{*}$ & \multicolumn{2}{|c|}{$4.2^{*}$} & $\mathrm{NMH}$ \\
\hline LL & $18.4^{*}$ & \multicolumn{2}{|c|}{$4.0^{*}$} & $\mathrm{NMH}$ \\
\hline SW & $\begin{array}{l}1.1 \\
4.7\end{array}$ & \multicolumn{2}{|c|}{1.6} & $\mathrm{np}$ \\
\hline MBL & \multirow{2}{*}{$\begin{array}{c}4.7 \\
18.9^{*}\end{array}$} & \multicolumn{2}{|c|}{$3.2^{*}$} & $\mathrm{np}$ \\
\hline PO:MBL & & \multicolumn{2}{|c|}{2.0} & $\mathrm{NMH}$ \\
\hline \multicolumn{5}{|l|}{ Day 12} \\
\hline $\mathrm{PO}$ & $10.6^{*}$ & \multicolumn{2}{|c|}{$5.0^{*}$} & $\underline{\mathrm{NMH}}$ \\
\hline LL & $10.8^{*}$ & \multicolumn{2}{|c|}{$4.1^{*}$} & $\underline{\underline{\mathrm{MH}}}$ \\
\hline SW & 0.5 & \multicolumn{2}{|c|}{$2.4^{*}$} & $\overline{\mathrm{np}}$ \\
\hline MBL & $\begin{array}{l}2.0 \\
5.4^{*}\end{array}$ & \multicolumn{2}{|c|}{$2.9^{*}$} & np \\
\hline PO:MBL & $5.4^{*}$ & \multicolumn{2}{|c|}{$9.6^{*}$} & $\underline{\underline{N M H}}$ \\
\hline $\begin{array}{l}\text { ANCOVA } \\
\text { PO with } \\
\text { MBL }\end{array}$ & $\begin{array}{c}\text { Food } \\
\text { treatment } \\
(\mathrm{df}=2,6)\end{array}$ & $\begin{array}{l}\text { ontainer } \\
\text { treatment) } \\
\text { If }=6,1)\end{array}$ & $\begin{array}{c}\text { MBL } \\
(\mathrm{df}=1,125)\end{array}$ & $\begin{array}{l}\text { HSD groupings } \\
\text { for Food } \\
\text { treatment }\end{array}$ \\
\hline Day 6 & $23.2^{*}$ & $2.9^{*}$ & $34.6^{*}$ & $\mathrm{NMH}$ \\
\hline Day 12 & $6.0^{*}$ & $9.4^{*}$ & $125.0^{*}$ & $\underline{\mathrm{NMH}}$ \\
\hline
\end{tabular}

development differed from Heliocidaris tuberculata. The anterolateral arms of $C$. rodgersii remained as small protrusions that barely extended beyond the larval body and the preoral and posterodorsal arms and associated skeletal rods and dorsal arch did not develop (Figs. 1 \& 5).

Fig. 5 shows the appearance of Centrostephanus rodgersii larvae in the 3 treatments. 12 and $16 \mathrm{~d}$ old larvae show obvious differences in LL, PO and AW (Fig. 5). The morphometric data for each treatment are plotted in Fig. 6.

\section{Morphometry of larval growth}

Larvae in the $\mathrm{H}$ and $\mathrm{M}$ treatments grew through the experiment, while unfed larvae arrested development between Day 6 and 9 (Fig. 6). It is not known if the decrease in size of unfed larvae in some experiments was due to shrinkage of larvae or to higher mortality of larger larvae. Most unfed larvae survived for $30 \mathrm{~d}$ and some for up to $38 \mathrm{~d}$. Larvae in $\mathrm{M}$ treatments were reared for $47 \mathrm{~d}$. They were well short of the

\section{Centrostephanus rodgersii}

Centrostephanus rodgersii eggs from Expts 1, 2 and 3 had mean diameters of $108 \pm 0.36 \mu \mathrm{m}, 108 \pm 0.44 \mu \mathrm{m}$ and $103 \pm 0.32 \mu \mathrm{m}$ respectively (each with $\mathrm{n}=60$ ). Early development of $C$. rodgersii is typical of echinoids with the prism stage reached $45 \mathrm{~h}$ after fertilisation and the postoral arms developed first. Thereafter,

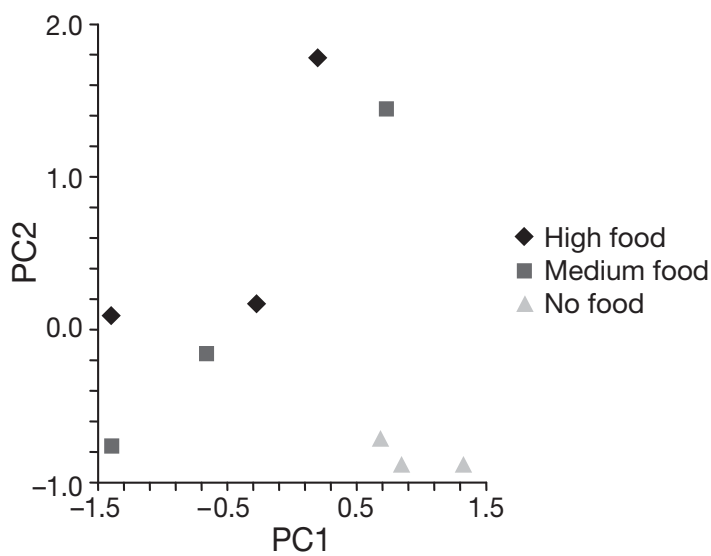

Fig. 4. Heliocidaris tuberculata. Principal component analysis of larval data on Day 12 for the means of the 6 parameters (see Fig. 1 for abbreviations) PO, MBL, BW, SL, SW and BP ( $=9$ ). This plot of first and second principal components indicates that larvae differed morphologically among the 3 treatments primarily due to arm length settlement stage (ca. 5 mo, Huggett et al. 2005) and had no sign of a developing juvenile rudiment.

There was no difference between treatments for all parameters across the 3 experiments for Centrostephanus rodgersii from Days 3 to 6 except for SW which diverged from Day 4 (Fig. 6b). From Day 6 to the end of the experiment SW of fed larvae was larger than in unfed ones and this was significant on Day 6 (Table 3, Fig. 6b). SW increased steadily in fed larvae until Day 9. As for Heliocidaris tuberculata, the stomach wall of fed $C$. rodgersii larvae became pigmented while remaining transparent in unfed ones (Fig. 5)

The body profile of larvae in the 3 treatments began to differ from Day 6 (Fig. 6). PO was ranked according to food level (Fig. 6a). ANOVA indicated that unfed

Table 2. Heliocidaris tuberculata. Eigenvector coefficients for Factor 1 and 2 from principal component analysis of larval data on Day 12. See Fig. 1 for variable abbreviations

\begin{tabular}{|lrr|}
\hline Variable & Factor 1 & Factor 2 \\
\hline PO & 0.36 & -0.52 \\
SW & -0.42 & -0.41 \\
MBL & -0.37 & 0.53 \\
BP & -0.47 & -0.05 \\
SH & -0.35 & -0.53 \\
BW & -0.46 & 0.00 \\
\hline
\end{tabular}




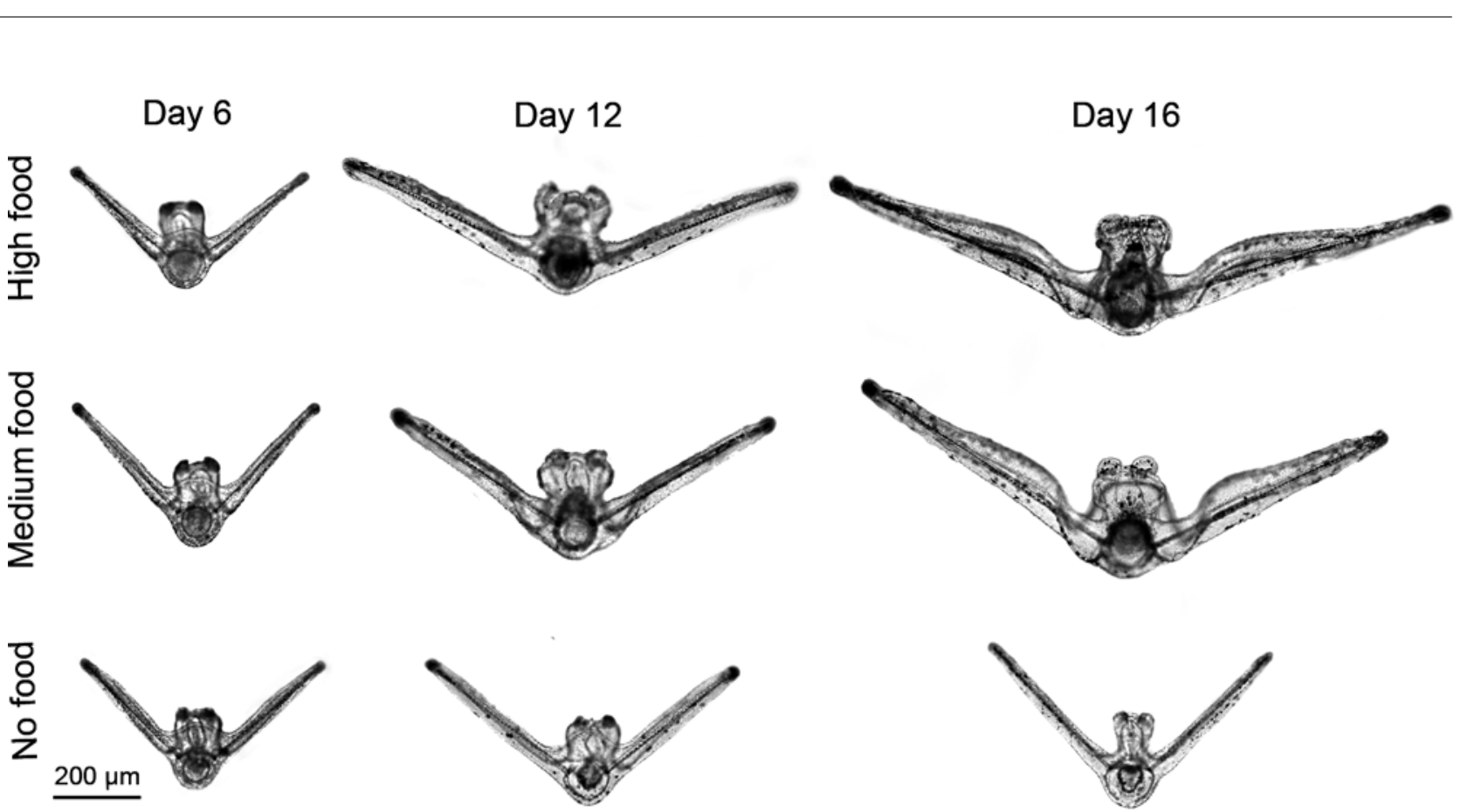

Fig. 5. Centrostephanus rodgersii. Larvae on Days 6, 12 and 16 (columns) from 3 food treatments (rows)

larvae had significantly shorter PO than larvae in the $M$ treatment on Day 6, and larvae in the $\mathrm{H}$ treatment on Day 12 (Table 3, Fig. 6a). The MBL of fed larvae were similar and were longer than those of unfed larvae from Day 6 onwards (Fig. 6c). Differences became statistically significant only on Day 12 , with an interaction between MBL and Experiment (ANOVA, Table 3).
SW was smaller in unfed larvae on Days 6 and 12, but on Day 12 there was an interaction between Food and Experiment (Table 3). PO and MBL of larvae in the $\mathrm{H}$ and $M$ treatments increased during the experiment. PO:MBL ratios were significantly greater in $\mathrm{H}$ larvae than in unfed ones on Day 12 (Table 3, Fig. 6d). After adjusting for the covariate MBL, PO differed signifi-

Table 3. Centrostephanus rodgersii. ANOVA F-ratios, ANCOVA F-ratios and Tukey's HSD multiple-comparison tests on data for larval measurements taken on Days 6 and 12. H, M and N: high, medium and no food treatment. Underlined letters: treatments did not differ significantly. Significance: ${ }^{*} p<0.05$. Expt: experiment. np: Tukey's HSD not performed. See Fig. 1 for all other abbreviations

\begin{tabular}{|c|c|c|c|c|c|c|}
\hline & $\begin{array}{c}\text { Expt } \\
(\mathrm{df}=2,18)\end{array}$ & $\begin{array}{c}\text { Food } \\
\text { treatment } \\
(\mathrm{df}=2,4)\end{array}$ & $\begin{array}{l}\text { Expt } \times \text { Food } \\
\text { treatment } \\
(\mathrm{df}=4,18)\end{array}$ & $\begin{array}{c}\text { Container } \\
(\text { Expt } \times \text { Food treatment }) \\
(\mathrm{df}=18,378)\end{array}$ & \multicolumn{2}{|c|}{$\begin{array}{l}\text { Tukey's HSD } \\
\text { grouping for } \\
\text { Food treatment }\end{array}$} \\
\hline \multicolumn{7}{|l|}{ Day 6} \\
\hline $\mathrm{PO}$ & 1.6 & $7.6^{*}$ & 0.2 & $12.9^{*}$ & \multicolumn{2}{|c|}{ MHN } \\
\hline LL & 1.8 & $7.7^{*}$ & 0.3 & $11.5^{*}$ & \multicolumn{2}{|c|}{$\underline{\mathrm{MHN}}$} \\
\hline SW & $8.9^{*}$ & $30.4^{*}$ & 1.4 & $3.0^{*}$ & \multicolumn{2}{|c|}{$\overline{\mathrm{HMN}}$} \\
\hline MBL & $5.2^{*}$ & 5.4 & 1.1 & $5.4^{*}$ & \multicolumn{2}{|c|}{$\mathrm{np}$} \\
\hline PO:MBL & 0.3 & 0.9 & 0.0 & $10.4^{*}$ & \multicolumn{2}{|c|}{ np } \\
\hline \multicolumn{7}{|l|}{ Day 12} \\
\hline $\mathrm{PO}$ & $6.7^{*}$ & $9.7^{*}$ & 1.7 & $13.5^{*}$ & \multicolumn{2}{|c|}{$\underline{\mathrm{HMN}}$} \\
\hline LL & $5.8^{*}$ & $9.5^{*}$ & 1.8 & $14.0^{*}$ & \multicolumn{2}{|c|}{$\overline{\mathrm{HMN}}$} \\
\hline SW & $7.8^{*}$ & $12.5^{*}$ & $7.0^{*}$ & $2.1^{*}$ & \multicolumn{2}{|c|}{$\overline{\mathrm{np}}$} \\
\hline MBL & 2.5 & $11.5^{*}$ & $3.5^{*}$ & $2.6^{*}$ & \multirow{2}{*}{\multicolumn{2}{|c|}{$\begin{array}{c}n p \\
\underline{H M N} \\
\end{array}$}} \\
\hline PO:MBL & $9.4^{*}$ & $8.4^{*}$ & 0.8 & $9.0^{*}$ & & \\
\hline $\begin{array}{l}\text { ANCOVA } \\
\text { PO with MBL }\end{array}$ & $\begin{array}{c}\text { Expt } \\
(\mathrm{df}=2,18)\end{array}$ & $\begin{array}{l}\text { Food } \\
\text { treatment } \\
(\mathrm{df}=2,4)\end{array}$ & $\begin{array}{l}\text { Expt } \times \text { Food } \\
\text { treatment } \\
(\mathrm{df}=4,18)\end{array}$ & $\begin{array}{c}\text { Container } \\
(\text { Expt } \times \text { Food treatment }) \\
(\mathrm{df}=18,1)\end{array}$ & $\begin{array}{c}\text { MBL } \\
(\mathrm{df}=1,377)\end{array}$ & $\begin{array}{l}\text { HSD groupings } \\
\text { for Food } \\
\text { treatment }\end{array}$ \\
\hline Day 12 & $7.9^{*}$ & $7.5^{*}$ & 1.3 & $13.0^{*}$ & $41.6^{*}$ & $\underline{\mathrm{HMN}}$ \\
\hline
\end{tabular}



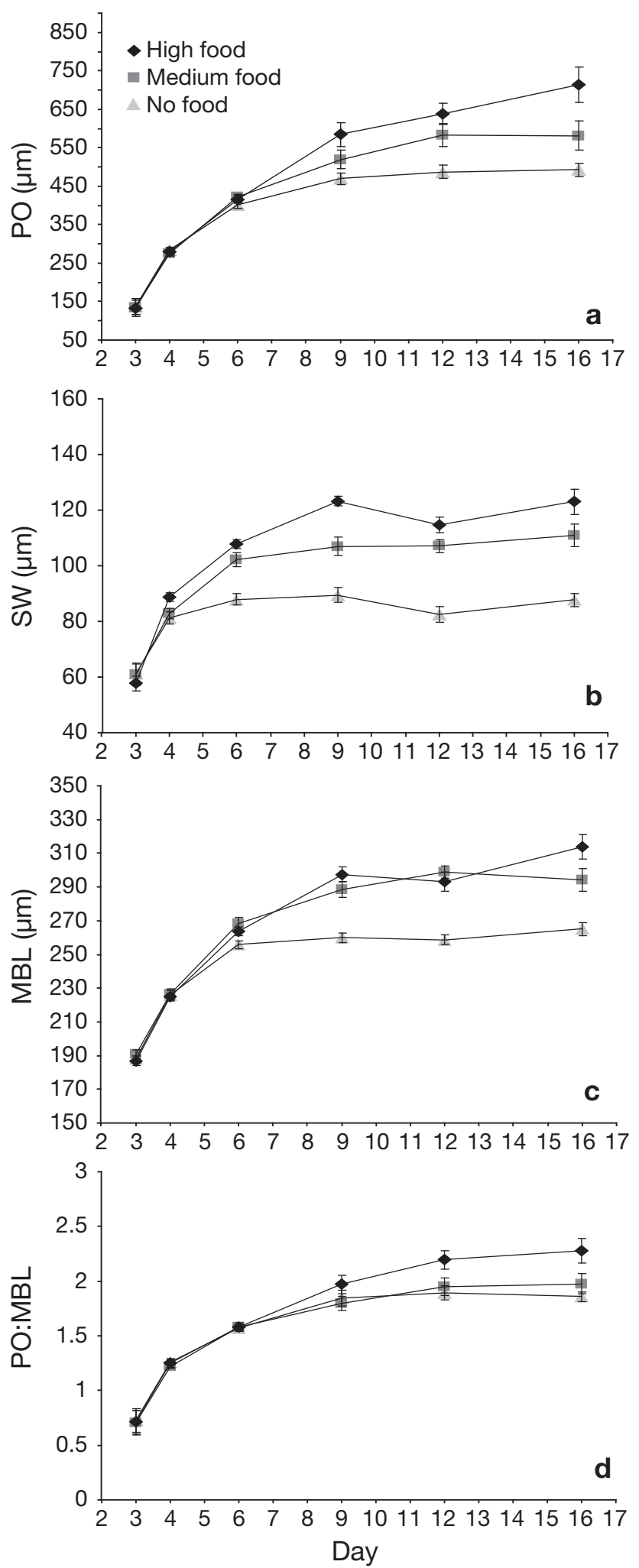

Fig. 6. Centrostephanus rodgersii. Measurements of larvae over time: (a) mean length of both postoral arms (PO), (b) Stomach width (SW), (c) Midline body length (MBL), (d) PO:MBL ratio. Combined mean values from all 3 C. rodgersii experiments $\pm \mathrm{SE}$ cantly between food treatments at Day 12 and was greater in high fed than unfed larvae (ANCOVA, Table 3). Least squares means for the $H, M$ and $N$ treatments were 622, 562 and 499 respectively, and 282 for the covariate MBL. On Day 12 the PO:MBL ratios of the larvae in the $\mathrm{H}, \mathrm{M}$ and $\mathrm{N}$ treatments were $2.20 \pm 0.09,1.95 \pm 0.08$ and $1.89 \pm 0.07$ respectively (each with $\mathrm{n}=135$ ).

According to ANOVA and ANCOVA, larvae from the $\mathrm{H}$ treatment showed highest $\mathrm{PO}$ in relation to $\mathrm{MBL}$, while unfed larvae never exhibited a disproportionate increase in PO. Some containers had a significant effect (Table 3), but this did not affect the overall result.

Mean AW of $16 \mathrm{~d}$ old larvae from the $\mathrm{H}, \mathrm{M}$ and $\mathrm{N}$ treatments (each with $\mathrm{n}=30$ ) were $114 \pm 4.3 \mu \mathrm{m}, 88 \pm$ $3.5 \mu \mathrm{m}$ and $70 \pm 1.4 \mu \mathrm{m}$ respectively, and greatest in larvae from the $\mathrm{H}$ treatment (ANOVA, $F_{2,6}=26.7, \mathrm{p}<$ 0.005). The $H$ treatment produced the largest larvae, on Day 30 they had a mean LL $=1199 \pm 138 \mu \mathrm{m}, \mathrm{PO}=$ $1059 \pm 131 \mu \mathrm{m}, \mathrm{SW}=157 \pm 14 \mu \mathrm{m}$, and $\mathrm{MBL}=370 \pm$ $17 \mu \mathrm{m}$ (each with $\mathrm{n}=45$ ).

\section{Principal component analysis}

PCA of the means for 6 parameters from all Centrostephanus rodgersii experiments on Day 12 is shown in Fig. 7 and Table 4. The first principal component represented $77 \%$ of the variation. Coefficients for the first eigenvector were all negative and of a similar absolute value $(-0.72$ to -0.95 , Table 4$)$. Thus the first principal component can be interpreted as being representative of larval size. The second principal component accounted for $12 \%$ of the variation. Coefficients for the

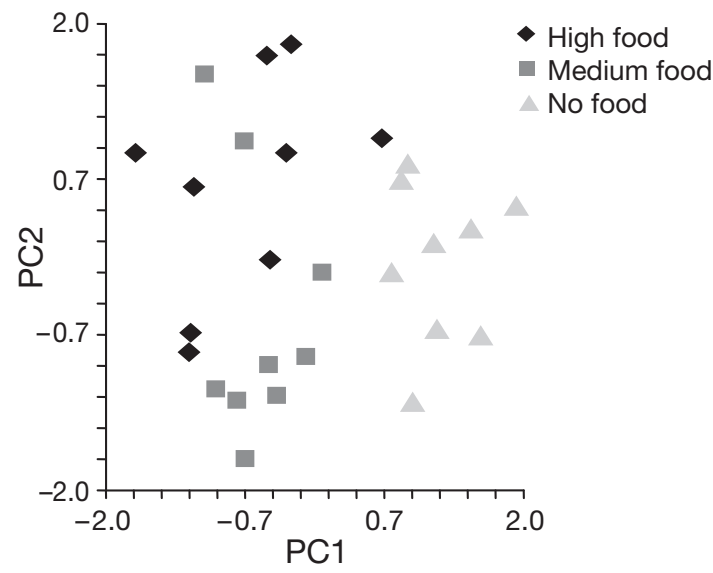

Fig. 7. Centrostephanus rodgersii. Principal component analysis of the means from 3 experiments on Day 12 for the 6 parameters $\mathrm{PO}, \mathrm{MBL}, \mathrm{BW}, \mathrm{SL}, \mathrm{SW}$ and $\mathrm{BP}$ (each with $\mathrm{n}=27$ ). This plot of first and second principal component indicates that larvae differed morphologically between the 3 treatments, primarily due to size differences 
Table 4. Centrostephanus rodgersii. Eigenvector coefficients for Factors 1 and 2 from the principal component analysis of larval data from all 3 treatments on Day 12. See Fig. 1 for variable abbreviations

\begin{tabular}{|lrr|}
\hline Variable & Factor 1 & Factor 2 \\
\hline PO & -0.72 & 0.64 \\
SW & -0.95 & 0.04 \\
MBL & -0.94 & -0.00 \\
BP & -0.84 & -0.33 \\
SH & -0.94 & 0.16 \\
BW & -0.85 & -0.42 \\
\hline
\end{tabular}

second Eigenvector were both positive and negative contrasting the body basket (BW and BP) with $\mathrm{PO}$ (Table 4).

The plot of the first principal component against the second one (Fig. 7) represents $89 \%$ of the variation. Data from the 3 treatments show clustering from left to right with respect to food concentration (high to none). The 2 data points from the $\mathrm{M}$ treatment clustered with the $\mathrm{H}$ treatment are from replicates with long PO. The PCA indicated that larvae from each treatment differed morphologically, mainly due to the size and the long $\mathrm{PO}$ of larvae from the $\mathrm{H}$ treatment.

\section{DISCUSSION}

The typical echinopluteus of Heliocidaris tuberculata exhibited the plastic arm growth response to food conditions reported for many echinoids (Table 5), while the 2-armed larva of Centrostephanus rodgersii did not, as is also the case for the 2-armed larvae of Diadema species (McAlister 2008). By Day 6 the larval profile of $H$. tuberculata differed depending on the feeding regime. The PO became longer in unfed larvae, while body size (MBL) did not differ among all treatments. As a result, unfed larvae had a greater PO:MBL ratio indicating plastic arm growth in these echinoplutei in response to different food conditions. According to PCA, unfed $H$. tuberculata larvae were distinct from those in the $\mathrm{M}$ and $\mathrm{H}$ treatments due to the phenotypic plasticity response. This is known from growth analysis in other plutei (Hart \& Scheibling 1988, Sewell et al. 2004, Byrne et al. 2008). Larvae in the $\mathrm{N}$ treatment did not arrest development and may have been sustained by dissolved nutrients or bacteria present in the FSW.

The magnitude of plastic arm growth in echinoplutei differs among species and may be influenced by phylogeny and latitude (Table 5). For example, the arm growth response to food conditions in Heliocidaris tuberculata was similar to that documented for another temperate echinometrid, Evechinus chloroticus (Sewell et al. 2004), but contrasts with the absence of this phenomenon in tropical echinometrids (McAlister 2008). Differences in the magnitude of arm plasticity response are also suggested to be influenced by the degree of maternal investment (egg size) (Reitzel \& Heyland 2007), but the data are mixed. Among closely related species of subtropical clypeasteroid echinoids and tropical ophiotrichid ophiuroids, plutei of species with small eggs have a greater plastic arm growth response than species with big eggs (Podolsky \& McAlister 2005, Reitzel \& Heyland 2007). In contrast, temperate strongylocentrotids show the opposite trend with plutei of large egg species having a greater phenotypic plasticity response (McAlister 2007). The relationship between egg size and arm growth plasticity is not straight forward, and a recent study highlights the importance of egg quality (maternal provisioning) rather than egg size per se in echinoid larval growth (Byrne et al. 2008).

In Centrostephanus rodgersii, increased food levels resulted in a general increase of all larval body parameters measured. Unfed larvae arrested growth between Days 6 and 9. As they remained alive for up to $38 \mathrm{~d}$, they may have been sustained by nutrients in the FSW. PO:MBL ratios indicated that the body profile was similar in larvae from all treatments. $\mathrm{H}, \mathrm{M}$ and $\mathrm{N}$ treatments produced the largest, intermediate and smallest sized larvae, respectively. The PO:MBL ratio was highest for $C$. rodgersii larvae in the $\mathrm{H}$ treatment due to the enhanced growth of the postoral arms. This is the highest PO:MBL ratio recorded for echinoplutei (Table 5). Different food treatments resulted in distinct differences in arm length in the larvae of $C$. rodgersii and other diadematids but not in plasticity (McAlister 2008). Thus, it seems unlikely that a plastic arm response would be induced in these larvae regardless of nutritive environment. PCA confirmed that the larvae of $C$. rodgersii in each treatment were morphologically distinct and that clustering was based on larval size. The interactions between treatment and experiment for MBL and SW on Day 12 highlight the need for multiple experiments, as done here for C. rodgersii.

Phenotypic plasticity in arm growth in typical echinoplutei contributes to fitness by allowing the larvae to fine-tune allocation of resources into growing arms or accelerating juvenile rudiment formation, depending on the nutritive environment (Strathmann et al. 1992). With only 2 functioning arms, phenotypic reduction of arm length in response to high food conditions is unlikely to be adaptive in 'Echinopluteus transversus' larvae. These larvae have very long postoral arms which may be essential to maintain a sufficient surface area for particle capture by the ciliary band. It would be interesting to compare the total surface area of the ciliary band (total arm length) of 2 and 8 armed echinoplutei. 
Table 5. Phenotypic plasticity in postoral arm length of echinoplutei in response to food regime: data from the literature. Habitat: Subtr $=$ subtropical, Temp = temperate, Trop = tropical, Med = Mediterranean. Indicator: parameter used to determine the presence or absence of plasticity, PO:MBL = postoral arm length to midline body length, $\mathrm{PO}=$ postoral arm length, $\mathrm{SA}: \mathrm{PO}=\mathrm{stomach}$ area to postoral arm length, LL = larval length. Egg: Egg diameter. PLD: approximate planktonic larval duration. nd: No data

\begin{tabular}{|c|c|c|c|c|c|c|c|}
\hline Species & Habitat & $\begin{array}{l}\text { Algae provided } \\
\text { (cells } \mathrm{ml}^{-1} \text { ) }\end{array}$ & Indicator & $\begin{array}{c}\text { Ratio } \\
\text { PO:MBL }\end{array}$ & $\begin{array}{l}\text { Egg } \\
(\mu \mathrm{m})\end{array}$ & $\begin{array}{l}\text { PLD } \\
\text { (d) }\end{array}$ & Source \\
\hline \multicolumn{8}{|l|}{ Species showing phenotypic plasticity } \\
\hline Heliocidaris tuberculata & Temp & $\begin{array}{r}12000 \\
1200\end{array}$ & PO:MBL ${ }^{a}$ & $\begin{array}{l}1.5 \\
1.5 \\
1.7\end{array}$ & 96 & $\begin{array}{l}15 \\
42\end{array}$ & $\begin{array}{l}\text { Byrne et al. (2001), } \\
\text { present study }\end{array}$ \\
\hline Evechinus chloroticus & Temp & $\begin{array}{r}6000 \\
600 \\
0\end{array}$ & PO:MBL & $\begin{array}{l}1.7 \\
1.5 \\
1.7 \\
1.7\end{array}$ & nd & 23 & Sewell et al. (2004) \\
\hline Strongylocentrotus franciscanus & Temp & $\begin{array}{r}12000 \\
2000 \\
200 \\
5000 \\
500\end{array}$ & $\mathrm{PO}$ & $\begin{array}{l}\text { nd } \\
\text { nd } \\
\text { nd } \\
\text { nd } \\
\text { nd }\end{array}$ & $123-125$ & nd & $\begin{array}{l}\text { Miner (2005), } \\
\text { McAlister (2007) }\end{array}$ \\
\hline Strongylocentrotus purpuratus & Temp & $\begin{array}{r}12000 \\
2000 \\
200 \\
5000 \\
500\end{array}$ & $\mathrm{PO}$ & $\begin{array}{l}\text { nd } \\
\text { nd } \\
\text { nd } \\
\text { nd } \\
\text { nd }\end{array}$ & $82-85$ & nd & $\begin{array}{l}\text { Miner (2005), } \\
\text { McAlister (2007) }\end{array}$ \\
\hline Strongylocentrotus droebachiensis & Temp & $\begin{array}{r}5000 \\
200 \\
0\end{array}$ & PO:MBL & $\begin{array}{l}\text { nd } \\
\text { nd } \\
\text { nd }\end{array}$ & $153-159$ & nd & $\begin{array}{l}\text { Bertram \& Strathmann } \\
\text { (1998) }\end{array}$ \\
\hline Paracentrotus lividus & Med & $\begin{array}{r}2000 \\
0 \\
0\end{array}$ & PO:MBL & $\begin{array}{l}1.1 \\
1.3 \\
1.1\end{array}$ & 93 & 7 & Strathmann et al. (1992) \\
\hline \multirow[t]{2}{*}{ Lytechinus variegatus } & Trop & $\begin{array}{l}4000 \\
4000 \\
4000\end{array}$ & PO:MBL & $\begin{array}{l}1.6 \\
1.8 \\
1.9\end{array}$ & nd & 12 & Boidron-Mètairon (1988) ${ }^{\mathrm{b}}$ \\
\hline & & $\begin{array}{r}8000 \\
8000 \\
0\end{array}$ & PO:MBL & $\begin{array}{l}1.1 \\
1.3 \\
1.5\end{array}$ & 110 & 9 & $\begin{array}{l}\text { McEdward \& Herrera } \\
\text { (1999) }\end{array}$ \\
\hline Tripneustes gratilla & Temp & $\begin{array}{r}10000 \\
0\end{array}$ & PO:MBL & $\begin{array}{l}1.2 \\
1.4\end{array}$ & 85 & 21 & Byrne et al. (2008) \\
\hline Dendraster excentricus & Temp & $\begin{array}{r}6000 \\
2000 \\
500 \\
0 \\
5000 \\
300 \\
250\end{array}$ & PO:MBL & $\begin{array}{l}1.2 \\
1.3 \\
1.6 \\
1.6 \\
\text { nd } \\
\text { nd } \\
\text { nd }\end{array}$ & 129 & 17 & $\begin{array}{l}\text { Boidron-Mètairon (1988) }{ }^{\mathrm{b}} \\
\text { Hart \& Strathmann (1994) }\end{array}$ \\
\hline Mellita tenuis & Subtr & $\begin{array}{l}8000 \\
6000 \\
2000\end{array}$ & SA:PO & $\begin{array}{l}\text { nd } \\
\text { nd } \\
\text { nd }\end{array}$ & 99 & nd & Reitzel \& Heyland (2007) \\
\hline Clypeaster subdepressus & Subtr & $\begin{array}{l}8000 \\
6000 \\
2000\end{array}$ & $\mathrm{SA}: \mathrm{PO}$ & $\begin{array}{l}\text { nd } \\
\text { nd } \\
\text { nd }\end{array}$ & 150 & nd & Reitzel \& Heyland (2007) \\
\hline \multicolumn{8}{|c|}{ Species not showing phenotypic plasticity } \\
\hline Centrostephanus rodgersii & Temp & $\begin{array}{r}12000 \\
1200 \\
0\end{array}$ & $\mathrm{PO}: \mathrm{MBL}^{\mathrm{a}}$ & $\begin{array}{c}2 \\
1.8 \\
1.8\end{array}$ & 106 & $90-150$ & Present study \\
\hline Diadema antillarum & Trop & $\begin{array}{r}10000 \\
5000 \\
5000\end{array}$ & $\mathrm{PO}$ & $\begin{array}{l}\text { nd } \\
\text { nd } \\
\text { nd }\end{array}$ & 75 & 35 & $\begin{array}{l}\text { Eckert (1998), } \\
\text { McAlister (2008) }\end{array}$ \\
\hline Diadema mexicanum & Trop & $\begin{array}{l}1000 \\
5000 \\
1000\end{array}$ & $\mathrm{PO}$ & nd & 66 & nd & McAlister (2008) \\
\hline Echinometra lucunter & Trop & 5000 & $\mathrm{PO}$ & nd & 83 & nd & McAlister (2008) \\
\hline Echinometra viridis & Trop & $\begin{array}{l}5000 \\
1000\end{array}$ & $\mathrm{PO}$ & $\begin{array}{l}\text { nd } \\
\text { nd }\end{array}$ & 90 & nd & McAlister (2008) \\
\hline Echinometra vanbrunti & Trop & 5000 & $\mathrm{PO}$ & nd & 68 & nd & McAlister (2008) \\
\hline Strongylocentrotus droebachiensis & Temp & $\begin{array}{r}1000 \\
5000 \\
500\end{array}$ & $\mathrm{PO}$ & $\begin{array}{l}\text { na } \\
\text { nd } \\
\text { nd }\end{array}$ & nd & 36 & Meidel et al. (1999) \\
\hline Eucidaris tribuloides & Trop & $\begin{array}{l}5000 \\
1000\end{array}$ & $\mathrm{PO}$ & $\begin{array}{l}\text { nd } \\
\text { nd }\end{array}$ & 93 & nd & McAlister (2008) \\
\hline Eucidaris thouarsi & Trop & $\begin{array}{l}5000 \\
1000\end{array}$ & $\mathrm{PO}$ & $\begin{array}{l}\text { nd } \\
\text { nd }\end{array}$ & 86 & nd & McAlister (2008) \\
\hline Leodia sexiesperforata & Subtr & $\begin{array}{l}8000 \\
6000 \\
2000\end{array}$ & $\mathrm{SA}: \mathrm{PO}$ & $\begin{array}{l}\text { nd } \\
\text { nd } \\
\text { nd }\end{array}$ & 191 & nd & Reitzel \& Heyland (2007) \\
\hline Encope michelini & Trop & $\begin{array}{r}50000 \\
0\end{array}$ & LL & $\begin{array}{l}\text { nd } \\
\text { nd }\end{array}$ & 175 & 9 & Eckert (1995) \\
\hline
\end{tabular}


Our understanding of phenotypic plasticity of arm growth in echinoplutei is largely based on temperate northern hemisphere species which are amenable to laboratory culture and have relatively short development times (Table 5). Phenotypic plasticity may be advantageous for 8-armed echinoplutei in temperate zones as it would maximise fitness in response to the marked phytoplankton variability in these latitudes by allocating resources to juvenile development when possible, and thus reducing PLD (Strathmann et al. 1992). In contrast, most of the species that lack phenotypic plasticity are from tropical and sub tropical habitats (Table 5). Due to a variable food environment it is suggested that the cumulative fitness of short armed echinoplutei in both high and low food concentrations may be greater than that of long armed larvae in species that exhibit plastic arm growth (Miner \& Vonesh 2004). However, phenotypic plasticity is likely to have energetic costs and, in a complex changing environment, its outcome may not be adaptive due to the lag between the environmental signal and the growth response (DeWitt et al. 1998), as seen in the $2 \mathrm{~d}$ lag in the echinopluteal arm response (Miner \& Vonesh 2004).

The pattern of long postoral arms in well-fed diadematid larvae is opposite to that seen in typical echinoplutei (Table 5). The data do not support the hypothesis that starved Centrostephanus rodgersii larvae would develop long arms. In contrast to the imperative to reduce the planktonic phase through arm plasticity, the 2-armed 'Echinopluteus transversus' appears to be adapted for long planktonic periods and delayed allocation of resources to rudiment development. In addition, most of these larvae occur in tropical seas where phytoplankton levels are less variable. For the larvae of C. rodgersii a fixed phenotype closer to the optimum may be favoured (DeWitt et al. 1998). It may be possible to assess the condition of wild caught Centrostephanus larvae based on features such as PO and AW. These are the only diadematid larvae in the temperate waters of Australia and would be readily identified in plankton samples.

The postoral arms of diadematid larvae are up to $12 \mathrm{~mm}$ long, much longer than in typical echinoplutei, and present an unusual profile (Mortensen 1921, 1937, Eckert 1998, Emlet et al. 2002, Huggett et al. 2005, McAlister 2008). As the planktonic stage is considered to be risky (López et al. 1998, Lamare \& Barker 1999), the long-lived larvae of Centrostephanus rodgersii would be expected to have some mechanism of defense against predators. The large surface area projected by the long PO (9 to $24 \mathrm{~mm}$ ) of 'Echinopluteus transversus' larvae may provide some protection against predation, as shown for the spines of crustacean zoea larvae (Morgan 1989).
The long PLD of Centrostephanus rodgersii appears characteristic of diadematids, including temperate and tropical species with 'Echinopluteus transversus' larvae (Eckert 1998, Huggett et al. 2005). The PLD of Diadema antillarum varies between 2 to 4 (most larvae) and 7 to 8 mo (Hérnandez et al. 2006). In contrast, the PLD of Heliocidaris tuberculata and other 8-armed plutei from temperate and tropical locations is generally $<5$ wk (Table 5). The long PLD of diadematid larvae is similar to that of teleplanic (long distance) larvae (Scheltema 1971). The 2-armed diadematid pluteus may have evolved for enhanced dispersal in these largely tropical sea urchins. The long PLD of C. rodgersii may have been a factor underlying its recent colonisation of Tasmania from New South Wales, facilitated by climate change driven alterations of the East Australia Current (Ling et al. 2008).

In addition to its impact on food capture, the arm profile of echinoplutei influences swimming efficiency. Grunbaum \& Strathmann (2003) provide a biomechanical framework to assess the evolution and functional consequences of 2 versus 8 arms in echinoplutei. Hydromechanical considerations indicate that model plutei with 2 arms extending from the body at a low angle have an enhanced speed and weight carrying capacity, whereas model plutei with many arms extending at a high angle are slower swimmers but have high stability in turbulence. Larvae of Centrostephanus rodgersii and Heliocidaris tuberculata represent these contrasting models and could be used to address this hypothesis that arm angle should decrease with growth as a mechanism to increase weight bearing capacity. The 2-armed profile of 'Echinopluteus transversus' may reflect selection to increase the efficiency of swimming while maintaining feeding capacity as the larvae grow in size.

It appears that arm growth plasticity may be a feature of echinoplutei with a comparatively short planktonic period and that the response may be more marked in temperate echinoids from certain families (Table 5). As suggested by McAlister (2008), comparative studies of species with a broad tropical-temperate distribution could be used to address this question. Larvae of the pantropical species Tripneustes gratilla exhibit phenotypic plasticity in the temperate parts of its range (Byrne et al. 2008), but it is not known if they do so in tropical latitudes. The broad distribution of this species allows the hypothesis that phenotypic plasticity is influenced by latitude to be tested. Echinoids with long-distance dispersal, slow development or tropical species, whether they have typical or 2-armed plutei, may have a reduced or no capacity for plastic arm growth. Our results show that phenotypic response of echinoid larvae to differing food conditions is not universal and proposes a suite of testable 
hypotheses that arm plasticity in echinoplutei may be constrained by phylogeny, latitude and hydromechanical considerations.

Acknowledgements. The research was supported by a grant from the Australian Research Council (M.B.). Thanks to Professor G. Quinn for advice on statistics. Byrne laboratory staff and students assisted with algal and larval culture and challenging specimen collection. The experiments performed in this study comply with current Australian legislation.

\section{LITERATURE CITED}

Agrawal AA (2001) Phenotypic plasticity in the interactions and evolution of species. Science 294:321-326

Andrew NL, Byrne M (2007) Ecology of Centrostephanus. In: Lawrence JM (ed) Edible sea urchins: Biology and ecology, 2nd edn. Elsevier Science, Amsterdam, p 183-196

Bertram DF, Strathmann RR (1998) Effects of maternal and larval nutrition on growth and form of planktotrophic larvae. Ecology 79:315-327

Boidron-Mètairon IF (1988) Morphological plasticity in laboratory reared echinoplutei of Dendraster excentricus (Escholtz) and Lytechinus variegatus (Lamarck) in response to food conditions. J Exp Mar Biol Ecol 119:31-41

Byrne M, Emlet RB, Cerra A (2001) Ciliated band structure in planktotrophic and lecithotrophic larvae of Heliocidaris species (Echinodermata: Echinoidea): a demonstration of conservation and change. Acta Zool 82:189-199

Byrne M, Sewell MA, Prowse TAA (2008) Nutritional ecology of sea urchin larvae: influence of endogenous and exogenous nutrition on echinopluteal growth and phenotypic plasticity in Tripneustes gratilla. Funct Ecol 22:643-648

DeWitt TJ, Sih A, Wilson DS (1998) Costs and limits of phenotypic plasticity. Trends Ecol Evol 13:77-81

Dworjanyn SA, Pirozzi I (2008) Induction of settlement in the sea urchin Tripneustes gratilla by macroalgae, diatom biofilms and conspecifics: a role for bacteria? Aquaculture 274:268-274

Ebert TA (1982) Longevity, life-history, and relative body wall size in sea urchins. Ecol Monogr 52:353-394

Ebert TA (1996) Adaptive aspects of phenotypic plasticity in echinoderms. Oceanol Acta 19:347-355

Eckert GL (1995) A novel feeding strategy of the tropical sand dollar, Encope michelini (Agassiz) - adaptation to food limitation and an evolutionary link between planktotrophy and lecithotrophy. J Exp Mar Biol Ecol 187:103-128

Eckert GL (1998) Larval development, growth and morphology of the sea urchin Diadema antillarum. Bull Mar Sci 63:443-451

Emlet RB, Young CM, George SB (2002) Phylum Echinodermata: Echinoidea. In: Young CM, Rice ME, Sewell MA (eds) An atlas of marine invertebrate larvae. Academic Press, London, p 531-551

Fenaux L, Strathmann MF, Strathmann RR (1994) Five tests of food-limited growth of larvae in coastal waters by comparisons of rates of development and form of echinoplutei. Limnol Oceanogr 39:84-98

> George SB (1999) Egg quality, larval growth and phenotypic plasticity in a forcipulate seastar. J Exp Mar Biol Ecol 237: 203-224

> Grunbaum D, Strathmann RR (2003) Form, performance and trade-offs in swimming and stability of armed larvae. J Mar Res 61:659-691
Hart MW, Scheibling RE (1988) Comparison of shapes of echinoplutei using principal components analysis, with an application to larvae of Strongylocentrotus droebachiensis. In: Burke RD, Mladenov PV, Lambert P, Parsley RL (eds) Echinoderm biology. Balkema, Rotterdam, p 277-284

> Hart MW, Strathmann RR (1994) Functional consequences of phenotypic plasticity in echinoid larvae. Biol Bull (Woods Hole) 186:291-299

Hérnandez JC, Brito A, Cubero E, Garcia N, Girard D, Gonzàlez-Lorenzo G, Falcòn JM (2006) Temporal patterns of larval settlement of Diadema antillarum (Echinodermata: Echinoidea) in the Canary Islands using an experimental larval collector. Bull Mar Sci 78:271-279

Huggett MJ, King CK, Williamson JE, Steinberg PD (2005) Larval development and metamorphosis of the Australian diadematid sea urchin Centrostephanus rodgersii. Invertebr Reprod Dev 47:197-204

Keesing J (2007) Ecology of Heliocidaris. In: Lawrence JM (ed) Edible sea urchins: biology and ecology, 2nd edn. Elsevier Science, Amsterdam, p 339-351

Lamare MD, Barker MF (1999) In situ estimates of larval development and mortality in the New Zealand sea urchin Evechinus chloroticus (Echinodermata: Echinoidea). Mar Ecol Prog Ser 180:197-211

Ling SD, Johnson CR, Frusher SD, King CK (2008) Reproductive potential of a marine ecosystem engineer at the edge of a newly expanded range. Glob Change Biol 14:907-915

López S, Turon X, Montero E, Palacín C, Duarte CM, Tarjuelo I (1998) Larval abundance, recruitment and early mortality in Paracentrotus lividus (Echinoidea). Interannual variability and plankton-benthos coupling. Mar Ecol Prog Ser 172:239-251

Marchinko KB (2007) Feeding behaviour reveals the adaptive nature of plasticity in barnacle feeding limbs. Biol Bull (Woods Hole) 213:12-15

> McAlister JS (2007) Egg size and the evolution of phenotypic plasticity in larvae of the echinoid genus Strongylocentrotus. J Exp Mar Biol Ecol 352:306-316

> McAlister JS (2008) Evolutionary responses to environmental heterogeneity in Central American echinoid larvae: Plastic versus constant phenotypes. Evolution 62:1358-1372

McEdward LR, Herrera JC (1999) Body form and skeletal morphometrics during larval development of the sea urchin Lytechinus variegatus Lamarck. J Exp Mar Biol Ecol 232:151-176

> McShane PE, Anderson OF (1997) Resource allocation and growth rates in the sea urchin Evechinus chloroticus (Echinoidea: Echinometridae). Mar Biol 128:657-663

Meidel SK, Scheibling RE, Metaxas A (1999) Relative importance of parental and larval nutrition on larval development and metamorphosis of the sea urchin Strongylocentrotus droebachiensis. J Exp Mar Biol Ecol 240:161-178

> Miner BG (2005) Evolution of feeding structure plasticity in marine invertebrate larvae: a possible trade-off between arm length and stomach size. J Exp Mar Biol Ecol 315: $117-125$

Miner BG, Vonesh JR (2004) Effects of fine grain environmental variability on morphological plasticity. Ecol Lett 7: 794-801

> Morgan SG (1989) Adaptive significance of spination in estuarine crab zoeae. Ecology 70:464-482

Mortensen T (1921) Studies of the development and larval forms of echinoderms. GEC Gad, Copenhagen

Mortensen TH (1937) Contributions to the study of the development and larval forms of echinoderms III. K Dan Vidensk Selsk Skr Naturv Math 7:1-65 
Pedrotti ML, Fenaux L (1993) Effects of food diet on the survival, development and growth-rates of 2 cultured echinoplutei (Paracentrotus lividus and Arbacia lixula). Invertebr Reprod Dev 24:59-69

Podolsky RD, McAlister JS (2005) Developmental plasticity in Macrophiothrix brittlestars: Are morphologically convergent larvae also convergently plastic? Biol Bull (Woods Hole) 209:127-138

Quinn GP, Keough MJ (2002) Experimental design and data analysis for biologists. Cambridge University Press, New York, p 1-537

Reitzel AM, Heyland A (2007) Reduction in morphological plasticity in echinoid larvae: relationship of plasticity with maternal investment and food availability. Evol Ecol Res 9:109-121

Editorial responsibility: Steven Morgan,

Bodega Bay, California, USA
Scheltema RS (1971) Larval dispersal as a means of genetic exchange between geographically separated populations of shallow-water benthic marine gastropods. Biol Bull (Woods Hole) 140:284-290

Schiopu D, George SB (2004) Diet and salinity effects on larval growth and development of the sand dollar Mellita isometra. Invertebr Reprod Dev 45:69-82

Sewell MA, Cameron MJ, McArdle BH (2004) Developmental plasticity in larval development in the echinometrid sea urchin Evechinus chloroticus with varying food ration. J Exp Mar Biol Ecol 309:219-237

Strathmann RR, Fenaux L, Strathmann MF (1992) Heterochronic developmental plasticity in larval sea-urchins and its implications for evolution of nonfeeding larvae. Evolution 46:972-986

Submitted: February 13, 2008; Accepted: November 24, 2008 Proofs received from author(s): May 5, 2009 